\title{
Development strategies of modern enterprises: a study on Russian metallurgical industry
}

\author{
Daria Baklanovskaya ${ }^{1}$, Marat Goguadze $^{2}$ and Lyubov Shamina, ${ }^{3, *}$ \\ ${ }^{1}$ Russian Presidential Academy of National Economy and Public Administration, North-West Institute of Management, 199178 Saint \\ Petersburg, Russia \\ ${ }^{2}$ Baltic State Technical University "VOENMEH" named after D.F. Ustinov, Philosophy Department, 190015 Saint Petersburg, Russia \\ ${ }^{3}$ Baltic State Technical University "VOENMEH" named after D.F. Ustinov, Organization Management Department, 190015 Saint \\ Petersburg, Russia
}

\begin{abstract}
The development of the metal processing industry requires paying attention both to the environmental safety of technologies of metal processing and to the energy costs. We will look at the economic impact of reducing production costs by saving resources and using environmental engineering tools. Minimizing the cost of protecting the air and water, soils and perennial plantings, recycling and disposal of waste and protecting natural landscapes are an important aspect of the company's development strategy. The article discusses the implementation of elements of strategies announced by the largest steel companies-Novolipetsk and Magnitogorsk Metallurgical Plants, and Severstal PJSC. The definition of strategy has been given. The strategy, on the one hand, is presented as an element of the enterprise's interaction with the external environment. On the other hand, it is seen from the point of view of the company's activity on three levels: corporate-business-functional, each of which, in its turn, consists of certain elements. We highlight the main elements of company's strategies, which are (generalized) as a combination of operational efficiency and cost reduction (functional strategies) - for all the companies, as well as market leadership (corporate strategy) — only for NLMP. The SWOT-analysis of the activities of all companies highlighted common characteristics of their traits: low growth of the world and domestic economy, low level of use of metallurgical capacity worldwide; the policy of protectionism that replaced globalization, the introduction of duties to enter the markets, the fact that domestic companies have their own resource base, the full production cycle, and other factors.As a general conclusion, despite the complexity of the external environment, companies try to adhere to the stated strategy and maintain high performance of operating efficiency and dividends. Companies can be considered to be confirming to their strategies and a system of planned indicators.
\end{abstract}

\section{Introduction}

Strategy is an extremely popular topic in the scientific community today. The research, clarification and interpretation of this concept in practice are devoted to numerous scientific publications (Kvint V.L., Damodaran A., Grant R., Moborn R., Chan K., Shifrin M.B., Mintzberg G., Porter M. etc.).

\section{Methods}

In this article, the strategy will be considered in the context of the company's activities, as a "company strategy". Under the term "the development strategy of the company" we will mean the "chain of actions that will lead to the goals set", in connection with which the author suggests structuring it according to "periods, functional areas, etc." [2], and "a general concept that ensures coherence and sets a general direction for actions and decisions of an individual or organization" [1], and "the totality of methods and actions aimed at achieving set goals and implementing tasks" [3].

Thus, these definitions of the strategy have a meaningful similarity, which lies in the existence of a basic idea, a goal that must be achieved through concerted action.

Some authors also suggest considering the company strategy as a link between the company itself (its goals, objectives, resources and capabilities) and the external environment (customers, competitors, suppliers).

At the same time, the company strategy can be considered hierarchically, i.e. divided into several levels [5]:

1. The first level of strategy is corporate strategy:

- A strategy of different types of growth (concentrated, integrated, diversified);

- Reduction strategy;

2. The second level of strategy is business strategies:

- Investment strategy (intensive, selective);

- Capital withdrawal strategy;

* Corresponding author: $1 \mathrm{kshamina@rambler.ru}$ 
Table 1. Key characteristics of companies' activities.

\begin{tabular}{|c|c|c|c|c|c|}
\hline No. & $\begin{array}{l}\text { Company } \\
\text { name }\end{array}$ & $\begin{array}{l}\text { Key areas of the } \\
\text { business }\end{array}$ & Key assets & $\begin{array}{l}\text { Product } \\
\text { market }\end{array}$ & $\begin{array}{c}\text { Strategy (core } \\
\text { elements) }\end{array}$ \\
\hline 1. & $\begin{array}{l}\text { Novolipetsk } \\
\text { Metallurgical } \\
\text { Plant (NLMP) }\end{array}$ & $\begin{array}{l}\text { Raw materials, iron } \\
\text { ore, scrap, etc.; } \\
\text { steel; metal rolling. }\end{array}$ & $\begin{array}{lr}\text { Novolipetsk } & \\
\text { Metallurgical } & \text { Plant, } \\
\text { Stoilensky } & \text { Mining } \\
\text { Plant, NLMP } & \text { India, } \\
\text { Altai-Coke, } & \text { NLMP- } \\
\text { Kaluga } & \\
\end{array}$ & $\begin{array}{l}\text { Russia } \\
\text { (main), } \\
\text { Europe, } \\
\text { USA }\end{array}$ & $\begin{array}{l}\text { Operational efficiency } \\
\text { (by cash flow); } \\
\text { Improving the supply } \\
\text { of raw materials; } \\
\text { leadership in strategic } \\
\text { markets }\end{array}$ \\
\hline 2. & Severstal PJSC & $\begin{array}{l}\text { Raw materials, iron } \\
\text { ore, scrap, etc.; } \\
\text { steel; metal rolling. }\end{array}$ & $\begin{array}{l}\text { Cherepovets } \\
\text { Metallurgical Plant, } \\
\text { Severstal Resources, } \\
\text { Severstal Ross Steel }\end{array}$ & $\begin{array}{l}\text { Russia } \\
\text { (main), } \\
\text { Europe, } \\
\text { North } \\
\text { America, etc. }\end{array}$ & $\begin{array}{l}\text { Maximizing share } \\
\text { value, leadership in } \\
\text { profitability, high } \\
\text { dividends }\end{array}$ \\
\hline 3. & $\begin{array}{l}\text { Magnitogorsk } \\
\text { Metallurgical } \\
\text { Plant (MMP) }\end{array}$ & $\begin{array}{lr}\text { Raw } & \text { materials, } \\
\text { metal } & \text { products- } \\
\text { rolled, } & \text { hardware, } \\
\text { etc. } & \end{array}$ & $\begin{array}{l}\text { MMP, metal production } \\
\text { segment (Turkey), coal } \\
\text { mining segment (RF) }\end{array}$ & $\begin{array}{l}\text { Russia and } \\
\text { the } \\
\text { (main), the } \\
\text { Middle East, } \\
\text { Europe, etc. }\end{array}$ & $\begin{array}{l}\text { Growth of efficiency: } \\
\text { lower costs, leadership } \\
\text { on total returns for } \\
\text { shareholders; } \\
\text { operational and } \\
\text { functional efficiency }\end{array}$ \\
\hline
\end{tabular}

3. The third level is functional strategies:

- Operating, financial, innovative;

- Market (strategy of leadership in costs, differentiation, focus)

This approach allows us to formalize the very concept of "enterprise strategy" by highlighting its essential characteristics. For convenience, let us unite both of these outlooks on the company strategy and analyze the strategies of largest enterprises in the metallurgical industry.

\section{Results and Discussion}

The selection will consist of three of the largest Russian companies operating in the industry: Novolipetsk and Magnitogorsk Metallurgical Plants, and Severstal PJSC.

Let us consider the external environment of companies. About $64-70 \%$ of Russian products are sold in the domestic market, but all companies have foreign segments for the production of metal products, which sell it in local markets (USA, Europe, Middle East, etc.). The share of foreign markets that is controlled by the mentioned companies is much lower and varies between 5 and 20 percent. We need to note that Russian internal market is considered a turbulent environment [16], which leads to rapid changes in the export percentage of heavy industries.

It is worth noting that the strengths of all these companies are:

- their raw material supply: NLMP $(70 \%$ or higher with its own resources), Severstal PJSC is supplied with $60-65 \%$ of the required coal and $100 \%$ of iron ore; MMP has the same situation as Severstal;

- diversified business structure;

- having a full production cycle;

- geographical proximity of the raw material base;

- external threats include:

- decline in domestic steel demand due to the slowdown in the growth of the Russian economy. The global and Russian economies (3 and 2\% respectively for 2018) can be singled out as a common external problem [2018].

- introduction of U.S. protectionist steel import policy in 2018. This forces companies to calculate both

Table 2. Strategies announced by the companies.

\begin{tabular}{|l|l|l|l|}
\hline No. & Company name & \multicolumn{1}{|c|}{ Key areas of the business } & \multicolumn{1}{|c|}{ Strategy (core elements) } \\
\hline 1. & $\begin{array}{l}\text { Novolipetsk } \\
\text { Metallurgical } \\
\text { Plant (NLMP) }\end{array}$ & $\begin{array}{l}\text { Raw materials, iron ore, scrap, } \\
\text { etc.; steel; metal rolling. }\end{array}$ & $\begin{array}{l}\text { Operational efficiency (by cash flow); Improving } \\
\text { the supply of raw materials; leadership in strategic } \\
\text { markets }\end{array}$ \\
\hline 2. & Severstal PJSC & $\begin{array}{l}\text { Raw materials, iron ore, scrap, } \\
\text { etc.; steel; metal rolling. }\end{array}$ & $\begin{array}{l}\text { Maximizing share value, leadership in } \\
\text { profitability, high dividends }\end{array}$ \\
\hline 3. & $\begin{array}{l}\text { Magnitogorsk } \\
\text { Metallurgical } \\
\text { Plant (MMP) }\end{array}$ & $\begin{array}{l}\text { Raw materials, metal } \\
\text { products—rolled, hardware, etc. }\end{array}$ & $\begin{array}{l}\text { Growth of efficiency: lower costs, leadership on } \\
\text { total returns for shareholders; operational and } \\
\text { functional efficiency }\end{array}$ \\
\hline
\end{tabular}


external risks and income losses due to the narrowing of the external market.

- dependence on foreign markets (China);

The drivers of growth for companies in the industry are energy, infrastructure projects, automobile industry [18];

Risks include high dependence of financial indicators on the prices of metal products [17].

Weaknesses include:

- low share of high added value products. It is easier for companies to make pipes or sell rolled metal than to make products for the domestic engineering complex (which is very complex and orders batches of relatively small size).

Let us consider the strategies announced by the companies and make their decomposition (breakdown by level) to assess their adequacy [10].

For convenience, we will distribute the elements of strategies into components: external and internal.

Table 3. Classifying goals stated in companies' strategy.

\begin{tabular}{|c|c|c|c|}
\hline Company & $\begin{array}{c}\text { Corporate } \\
\text { strategy }\end{array}$ & \multicolumn{2}{|c|}{$\begin{array}{l}\text { Functional strategies } \\
\text { (operational, market) }\end{array}$} \\
\hline NILMP & $\begin{array}{l}\text { Leadership } \\
\text { in strategic } \\
\text { markets }\end{array}$ & $\begin{array}{l}\text { Operating } \\
\text { efficiency } \\
\text { (cash } \\
\text { flow) }\end{array}$ & $\begin{array}{l}\text { Reducing } \\
\text { the } \\
\text { consumption } \\
\text { of expensive } \\
\text { resources }\end{array}$ \\
\hline $\begin{array}{l}\text { Severstal } \\
\text { PJSC }\end{array}$ & & $\begin{array}{l}\text { Financial } \\
\text { strategy } \\
\text { (dividend } \\
\text { leadership) }\end{array}$ & $\begin{array}{l}\text { Operating } \\
\text { strategy } \\
\text { (profitability } \\
\text { leadership) }\end{array}$ \\
\hline & \multicolumn{3}{|c|}{ Common goal: maximizing share value } \\
\hline \multirow[t]{2}{*}{ MMP } & & $\begin{array}{l}\text { Operating } \\
\text { strategy: } \\
\text { efficiency } \\
\text { growth, } \\
\text { lower } \\
\text { production } \\
\text { costs }\end{array}$ & \\
\hline & \multicolumn{3}{|c|}{ Common goal: maximizing share value } \\
\hline
\end{tabular}

\subsection{Profitability}

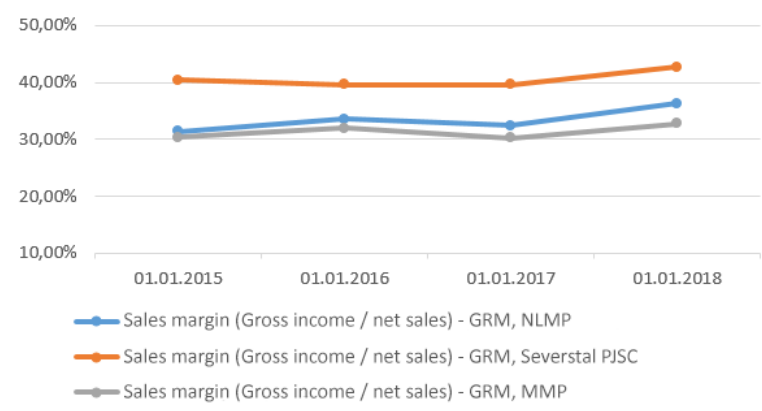

Fig. 1. Sales margin, \%.

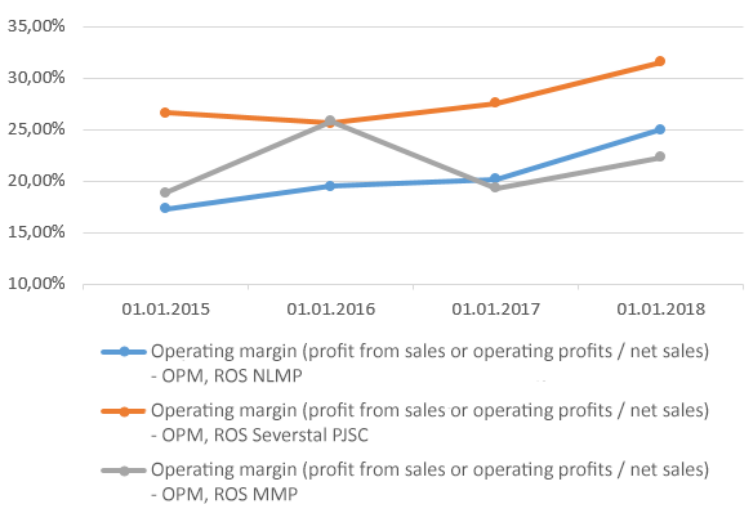

Fig. 2. Operating margin, $\%$.

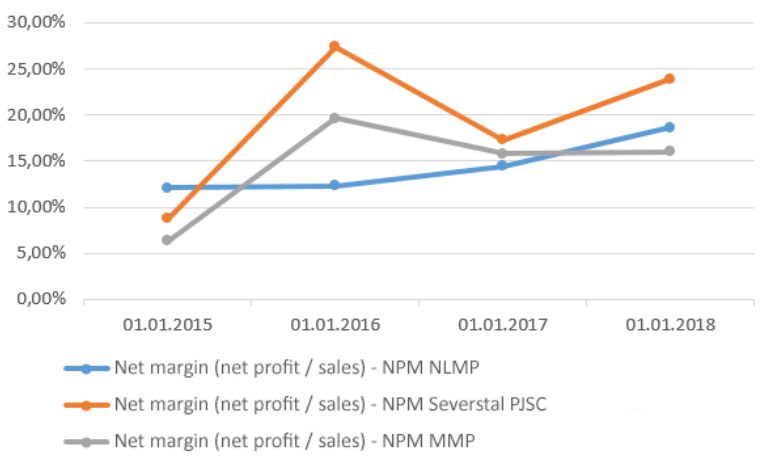

Fig. 3. Net margin, $\%$.

During the period under review, Severstal PJSC is leading, showing a higher level of profitability for every indicator. 2017 is a turning point for MMP, whose value from this year is sharply declining and further gets close to the profitability of the outsider-NLMP.

Differences in the values of indicators: gross margin in the range of $30-40 \%$, operating $17-20 \%$ (peak value $31.5 \%$ at Severstal) and net margin in the range of 6$12 \%$ (peak value $24 \%$ of Severstal) are explained by the value of cost and commercial, management and other expenses.

\subsection{Operating costs}

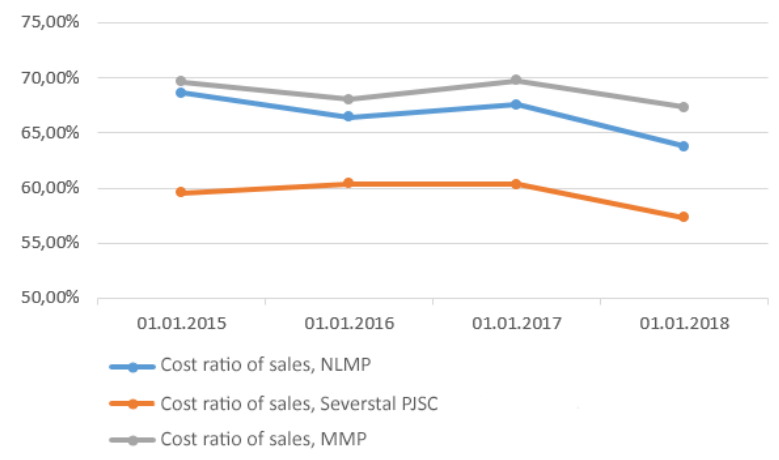

Fig. 4. Cost ratio, \%. 


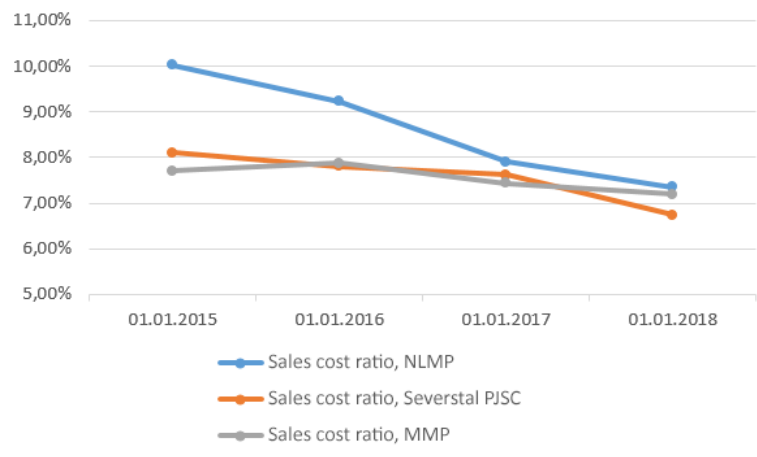

Fig. 5. Sales cost ratio, $\%$.

From the charts it is clear that Severstal PJSC is the leading company again: it has the lowest share of cost in revenue among competitors and the sales costs ratio. This indicator is also influenced by the dynamics of revenue, which was positive during the entire period only at MMK.

\subsection{Dividend yield, rub/share}

Table 4. Company dividends.

\begin{tabular}{|l|l|c|c|c|c|}
\hline \multirow{2}{*}{ Company } & \multirow{2}{*}{ Indicator } & \multicolumn{5}{|c|}{ Period } \\
\cline { 3 - 6 } & & $\mathbf{2 0 1 5}$ & $\mathbf{2 0 1 6}$ & $\mathbf{2 0 1 7}$ & $\mathbf{2 0 1 8}$ \\
\hline NLMP & $\begin{array}{l}\text { Dividend, } \\
\text { ruble/share }\end{array}$ & 6.95 & 9.22 & 14.04 & 22.81 \\
\hline MMP & $\begin{array}{l}\text { Dividend, } \\
\text { ruble/share }\end{array}$ & 0.89 & 1.962 & 2.786 & 5.902 \\
\hline \multirow{2}{*}{ Severstal } & $\begin{array}{l}\text { Dividend, } \\
\text { ruble/share }\end{array}$ & 58.88 & 80.6 & 110.05 & 160.73 \\
\hline
\end{tabular}

Thus, the leadership of Severstal in terms of dividend per share is confirmed.

\subsection{Leadership in strategic markets and increased supply of raw materials (for NLMP)}

The plant is oriented at the Russian market, as more than one third of its products are sold here. Representatives of the company specify that the strategic markets are the steel market (sales growth), as well as the increase in sales in the domestic market (up to $45 \%$ ) compared to 2013.

It is also possible that these sales are considered to be targeted at certain priority regions, as well as regions where there are traders with whom the company has developed long-standing relationships [12].

Table 5. NLMP's share of the markets in 2016.

\begin{tabular}{|l|c|}
\hline \multicolumn{1}{|c|}{ Production } & Market share, $\%$ \\
\hline Cold rolled & 27.1 \\
\hline Rolled with polymer coatings & 23.6 \\
\hline Steel & 22.0 \\
\hline Galvanized rolled & 20.1 \\
\hline Reinforcement & 19.9 \\
\hline Global slab market & 2.1 \\
\hline
\end{tabular}

For comparison, Severstal PJSC share in the Russian steel market is $21 \%$ [13]. The share of Magnitogorsk plant in the Russian rolled metal market is $17 \%$ [14]. Thus, the three companies under study plus Evraz mining company are nowadays leading in the rolled metal market, the shares of others are $9 \%$ and less.

In the context of reducing the consumption of expensive resources, NLMP optimized the purchase of energy resources and saved 700 million rubles during 2015 [14]. Additionally, NLMP has saved 700 million rubles after optimization of energy resources purchases and performing 344 optimizations of energy efficiency of its equipment complex that were aimed at increasing the share of self-generated energy and volume of utilization of secondary energy sources (almost $77 \%$ of the total generation of own electricity was provided by the utilization of secondary fuel gases), optimization of illumination system, decreasing losses in its steam and hot water supply grids, etc. [14].

\section{Conclusions}

1. The companies under consideration are now the leaders of the metallurgical market. Their stated strategies are similar and focus on operational efficiency and cost reduction (functional strategies), as well as market leadership (NLMP - corporate strategy);

2. If we consider the strategy as a link between the company and the business environment, the external factors affecting all companies are the same: low growth of the global and Russian economy, low loading of metallurgical capacities in the world (below 70\%); policy of protectionism (trade wars, import duties on metal products); difficulty of prediction of the growth of the cost of metallurgical companies and price volatility in the market; extremely strong impact of falling/rising prices in China on the world prices. Companies have their own resource base, have established sales links, have a full production cycle;

3. Severstal PJSC leads the margins and costs, with other companies slightly lower but in an acceptable range.

4. Companies are among the 4 leaders in the Russian rolled metal market (from 17 to $20 \%$ );

5.NLMP is also working to reduce the consumption of expensive resources (as stated in its strategy).

As a general conclusion, despite the complexity of the external environment, companies try to adhere to the stated strategy and maintain high performance of operating efficiency and dividends. Companies can be considered to be based on their strategies and systems of planned indicators.

\section{References}

1.R. Grant, Modern Strategic Analysis, St. Petersburg, 19 (2018)

2.M. Fishermen, How to restore order in his business, Moscow, Icarus (2014)

3.https://www.gd.ru/articles/9584-strategiyarazvitiya-predpriyatiya (2019) 
4.V.L. Kvint, Strategic Governance and Economics in the Global Emerging Market. https://www.livelib.ru/author/434199/top-kvint-vladimirlvovich (2019)

5. V.G. Cogdenko, M.V. Melnik, Management of company value: textbook. M.: Unity, 88 (2014)

6.https://www.severstal.com/rus/ir/results_reports/an nual_reports/, http://www.mmk.ru/for_investor/financial_statements/m sfo/, https://nlmk.com/ru/ir/reporting-center/annualreports/ (2019)

7.http://www.slcapitalservices.com/files/12-04-

02_CHMF_SOVL_rus.pdf (2019)

8.https://smart-lab.ru/blog/530954.php (2019)

9.https://revolution.allbest.ru/management/00424455 - 0. html (2019)

10.https://www.rbc.ru/economics/25/01/2019/5c4b1f 5f9a7947ce9d3e3133 (2019)

11. https://smart-lab.ru/q/CHMF/f/y/ (2019)

12.https://moneymakerfactory.ru/spravochnik/nlmkistoriya-metallurgicheskogo-giganta/ (2019)

13.https:/www.rbc.ru/vo/interview/13/12/2016/584fa c979a7947a99f9eb132 (2019)

14.http://www.metaprom.ru/news/metalloprokat/2403-16-n23088/ (2019)

15.http://www.metaprom.ru/news/metalloprokat/2403-16-n23088/ (2019)

16. V. Yanovskiy, L. Shamina, A. Shmatko, Adaptability as a tool for managing an enterprise in a turbulent external environment // Advanced Science Letters 24 6323-6325 ISSN: 1936-6612 EISSN: 19367317 DOI: 10.1166/ASL.2018.13043 (2018)

17. A.O. Nedosekin, A.D. Shmatko, Z.I. Abdoulaeva, Fuzzy Preliminary Evaluation of Industrial Risks, Proceedings of XX IEEE International Conference on Soft Computing and Measurements (SCM) DOI: 10.1109/SCM.2017.7970711 (2017)

18. E.P. Ilyenko; E.I. Rejshahrit, A.D. Shmatko, Qualimetric, Model as a Tool for Identifying the Cost of Activities on Occupational Safety in the Coal Enterprise Proceedings of XX IEEE International Conference on Soft Computing and Measurements (SCM) DOI: 10.1109/SCM.2017.7970675 (2017) 